\title{
Teknoloji ve Kent Yaşamında Dönüşüm: Akıllı Kentler*
}

\author{
Technology and Transformation In Urban Life: Smart Cities
}

\section{Erhan ÖRSELLI}

Doç. Dr., Necmettin Erbakan Üniversitesi, SBF, Siyaset Bilimi ve Kaти Yönetimi, eorselli@erbakan.edu.tr https://orcid.org/0000-0003-3977-0099

\section{Can AKBAY}

Doktorant, Necmettin Erbakan Üniversitesi, SBE, Siyaset Bilimi ve Kamu Yönetimi, canakbay@hotmail.com https://orcid.org/0000-0002-3149-6251
Makale Başvuru Tarihi / Received: 26.03.2019

Makale Kabul Tarihi / Accepted: 06.05.2019 Makale Türü / Article Type: Araştırma Makalesi

\begin{abstract}
Anahtar
Kelimeler:

Kent,

Akullı Kent,

Sürdürülebilirlik,

$B \dot{I T}$

Türkiye, arttırmak için bilgi iletişim teknolojileri yaşamın her alanına entegre edilmektedir. Ayrıca hızlı nüfus artışı sonucu kentlerde ortaya çıkan ulaşım, enerji, su, sağllk, çevre ve güvenlik gibi birçok alandaki sorunun çözümünde de teknoloji bir araç olarak kullanılarak, kentlerin yoğunlaşan kent nüfusunun ortaya çıkardiğl sorunlara pratik çözümler için akıllı uygulamalar denenmektedir. Bunların sonucu olarak kentler daha çok dijitalleşmekte ve kentli dijital bir kimlik kazanmaktadır. Çoklu bir ağa dönüşsen yaşam alanlarında, toplumun refah düzeyini yükseltebilmek ve sürdürülebilir düzeyde devam ettirilebilmek için; nüfus, kaynak, çevre ve bilgi ișlem teknolojilerinin karşıllklı ve uygun olarak düzenlenmesi adeta bir zorunluluk haline gelmiștir. Bu süreçte giderek artan ve çeşitlenen hizmet beklentileri devletleri, kamu yönetimlerini ve yerel yönetimleri kentleri daha iyi analiz etmeye, sorunları önceden tahmin etmeye, sinırl kaynakları ileri teknoloji desteğiyle verimli kullanmaya zorlamaktadır. Bu durum, akıllı kent projelerinin doğuşunu ve yayılımını tetiklemiştir. Bu bağlamda çalışmanın temel amacı, dünyadaki akıllı kent uygulama örnekleri ile Türkiye'deki akıllı kent uygulamalarını karşılaştırmalı olarak ele almaktır. Çalışma nitel bir yöntemle oluşturulmuştur. Öncelikle akillı kent kavrami; ardından akıll kentlerin unsurları ve teknolojileri incelenecek, daha sonra ise dünyadaki örnek uygulamalar ile Türkiye'deki akıllı kent uygulamaları klyaslanarak değerlendirilecektir. Böylece Türkiye’nin, akıllı kent vizyonunda ulaştı̆̆ düzey daha net saptanabilecektir.
\end{abstract}

Keywords:

City,

Smart City,

Sustainability,

$B I T$,

Turkey,

\section{ÖZET}

Küresel büyüme ve kentsel nüfusun hızla artışıla ortaya çıkan sorunları çözebilmek için geleneksel kamu politikalarl terk edilmekte, vatandaşların yaşam kalitesini ve kamusal hizmetlerden memnuniyetlerini

\section{ABSTRACT}

To solve the problems generated from fast-changing world order; information and communication technologies are combined with daily life to improve citizens' quality of life and their satisfaction from public services. Besides, by using technology as a tool to solve problems that appear in cities, caused by rapid population growth, such as transportation, energy, water, health, environment, secure and security, smart combinations are being tried for practical solutions to problems caused by overpopulation in cities. As a result, cities become more digital and citizens gain the new digital identity. In life spaces which turn into a complex network, it is almost obligatory to regulate population, resources, environment and communication and information technologies in themselves to improve citizens' life quality and keep it in a sustainable level. Within this period, improving and diversifying service expectations push governments, public and local administrations to analyze cities better, predict the upcoming problems and use limited resources productively with the help of high technology. This situation has triggered to exist and expand smart city projects. In this context, the main aim of this research is determined to consider good examples of smart city projects and to discuss comparatively their reflections on cities in Turkey. The qualitative approach is used. Firstly, smart city concept and components and characteristics of smart cities will be examined and than good examples of the smart city implementations around the World and Turkey will be compared and evaluated. Thus, it will be possible to determine the level of Turkey in this regard and compare it with the developments around the World.

\footnotetext{
* Bu çalışma 1-3 Kasım 2018 tarihleri arasında Alanya'da gerçekleştirilen Alanya Uluslararası Yerel Yönetimler Sempozyumu'nda yazarlar tarafından sunulan "Bir Kenti Geleceğe Taşıma ve Kent Alışkanlıklarını Değiş̧tirme Projesi Olarak Akıllı Kentler" adlı bildirinin güncellenmiş ve gelişttirilmiş halidir.
} 


\section{GİRIŞ}

Yaşadığımız yüzyılda teknoloji, insanoğlunun yaşamının neredeyse her anına etki ederek adeta yaşamları kuşatmaktadır. Teknolojinin gelişim ve ilerleme seyri düşünüldüğünde çok yakın bir gelecekte, arabalar kendi kendilerine hareket ederek park yerini kendi bulacak, birbirleri ile haberleșecek ve mobil cihazlarla kontrol edilebilecek; elektrikli arabalar şarj kabloları ile değil, akıllı asfaltların üzerine entegre edilmiş şarj noktalarından enerji yükleyebilecek aynı zamanda elektrik direkleri de şarj istasyonları olarak işlev görebilecek; toplu taşıma için ray üzerinde otomatik olarak ilerleyen, toplu ulaşımda kişisel istikametlere erişimi mümkün kılan, ihtiyaç duyulduğunda akıllı telefonlarla çağrılabilen araçların görülmesi; belkide sabit trafik 1şıkları ve boyalı yaya geçitlerinin yerini sensör desteği ile yer değiştirebilen simülasyonlar alacaktır. Ayrıca yer altında sürtünmeyi ve aerodinamik direnci minimize eden, tüp sistemi içinde yol alan, kendi enerjilerini verimli kullanan turbo kapsüllerin kullanılması mümkün olabilecektir (Geleceğin Kentlerinde Mobilite, 2017).

Bilgi ve iletişim teknolojileri kent hayatını, kültürünü ve kentlilerin alışkanlıklarını çok hızlı bir şekilde değiştirmekte ve dönüştürmektedir. Bu dönüşümün sonucunda kentin kullanım şekilleri; vatandaşların istek ve beklentileri tamamen farklı boyutlara taşınmaktadır. Bugün kentler oldukça canlı, hareketli, üretken, yenilikçi, çekici olmakla beraber, maruz kaldığı yoğun nüfus akımları nedeniyle karmaşa, kayıtdışılık, trafik, sağlık, atık, enerji, su ve hava kirliliği, çarpık kentleşme, kaynaklara ulaşım, suç çeşit ve miktarlarındaki hızlı yükseliş gibi birçok sorunla yüzyüzedir (Akgül, 2017). Kentlerde yaşanan bu tür sorunlar; planlama, tasarım, finans, kentsel altyapı, hizmetlerin işletilmesinde ve yönetişiminde yeni bakış açılarının doğmasını tetiklemiş (Harrison ve Donnelly, 2011:1); kamu yönetimleri ve yerel yönetimler karşılaşılan bu problemlerin çözüm yollarını bulmaya ve yeni stratejiler geliştirmeye odaklanmışlardır (Mangır, 2016:19). Bu bağlamda sensörler, ağ bağlantıları, nesnelerarası etkileşim ve iletişim, yönetişim ve e-yönetişim, e-devlet, sürdürülebilirlik, insan odaklılık gibi yaklaşımlar 1990'lı yılların başından itibaren sıklıkla dile getirilmeye (Şahin ve Örselli, 2003:344; Şahin, 2016:254) başlanmış modern kentler için yaşam kalitesini iyileştirmek için "akıllı kent" vizyonu ön plana çıkmıştır. Nitekim uzun bir süredir vatandaşların yaşam kalitesini arttırmak için teknoloji yaşamla birleştirilerek ve yoğunlaşan kent nüfusuna pratik çözümler için akıllı uygulamalar geliştirilmektedir. Bunların sonucu olarak kentler daha çok dijitalleşmekte ve kentli dijital bir kimlik kazanmaktadır. Dolayısıyla bu durum, akıllı kent projelerinin doğuşunu ve yayılımını artırmıştır.

Akı1lı kentler, önceki yüzyılın kentsel gelecek vizyonlarına kadar uzanmasına rağmen son yirmi yılda doğmuş ve popüler olmuştur. Nitekim geleceğe dair vizyonlar, teknolojinin ve bulunulan dönemin üretim araçlarının etkisi altında şekillenip evrilmiştir. Akıllı olma stratejilerinin çoğunluğu kısa zamanda elde edilebilecek bir olgu olmamakla birlikte, uzun süreli bir çalışma ve kararlılıkla hayata geçirilmesi söz konusu olabilmektedir. Bu nedenle, geleceğin kentleri ile ilgili vizyon, akıllı kent söyleminin önemli bir olgusudur. Hem kent yönetiminin özellikle de yöneticiler, hem de vatandaşlar tarafindan bu vizyonun kavranması ve kabul edilmesi akıllı kent yaklaşımının başarıya ulaşması için oldukça önemlidir.

Akıllı kent kavramına getirilen her tanım akıllı kentin başka bir veya birkaç boyutuna dikkat çekmektedir. Genel olarak değerlendirildiğinde akıllı kentlerin üç ana özelliği taşıması gerekmektedir: Yenilik, sorun çözme becerisi ve bilgi iletişim teknolojileri. Sayılan bu üç özellik içerisinde en önemli bileşke, kamu yönetimlerinin sorunları çözme yeteneği ve sorunların çözümleri için teknolojinin kent yaşamına entegrasyonu sürecidir. Bu anlamda, kentin akıllılı̆̆ 1 , inovasyon süreçlerinin bilgi ve iletişim teknolojileri tarafından kolaylaştırıldığı herhangi bir yerin, şehrin veya bölgenin iç kalitesidir. Bu bağlamda iş birliğine, dijital altyapı araçlarına kentlilere sunduğu firsatlara bağlı olarak akıllılık derecesi değişmektedir. Ayrıca akıllı kent uygulamalarının en önemli hedeflerinden biri de karar alma süreçlerine büyük oranda vatandaş katılımının dahil edilmesidir. Yerel yönetimler ile kentliler arasında iletişim, geleneksel tarzdan dijital tabana doğru ne kadar çok kaymaya başlarsa o kadar etkili, yaygın ve hızlı olması ve vatandaş katılımının artması söz konusu olacaktır.

$\mathrm{Bu}$ bağlamda çalışmanın temel amacı akıllı kent uygulamaları konusunda dünyadaki örnek uygulamaların Türkiye'deki kent uygulamalarına yansımalarını karşılaştırmalı olarak ele almaktır. Çalışma nitel bir yöntemle oluşturulmuştur. Çalışmada öncelikle akıllı kentin kavramsal çerçevesi; ardından akı1lı kentlerin unsurları ve kullanılan teknolojileri ele alınmış, daha sonra ise dünyadaki örnek uygulamalar ile Türkiye'deki akıllı kent uygulamaları karşılaştırılarak değerlendirilmiştir. 


\section{AKILLI KENT: KAVRAMSAL ÇERÇEVE, UNSURLAR VE TEKNOLOJILER}

Tarih boyunca kentler "ilham olma" ve "ürkütme" zıtlıklarını barındıran dual bir yapıyı bünyesinde taşıyarak gelişmiştir. Bazılarını kentin gürültüsü, kalabalığı, sağlıksız koşulları ürkütse de, bazıları için kent, sürekli bir etkinlik, yoğunlaştıılmış iş enerjisi ve olağanüstü yenilik ve heyecan ortamıdır. Bazıları ise kenti tüketim ve keşif için baştan çıkarıcı ve pahalı yeni deneyimlerin olduğu bir oyun bahçesi olarak algılar. Bu yaklaşımların yanısıra, şirketler hızlı büyümek için bir merkez olarak değerlendirirken, şehir planlamacılar gelişme ve sorunların çözümü için büyük bir potansiyel olarak niteler. Bu yaklaşımların şekillenmesinde ekonomik durum, coğrafi konum ve kişisel deneyim kayda değer öneme sahiptir. Kent yaşamının sorunları karmaşıktır ve çözülmesi de zordur ama başarılı çözümler çok yönlü ve geniş kapsamlı özellik taşıdıklarından içinde birçok yeni firsat barındırır (Herzberg, 2017:19). Bu yüzden insanoğlu kenti gelecek olarak olarak algılamış ve tercihini ondan yana seçmiş görünmektedir.

Dünyada günde ortalama 200.000 kişinin kentlere göç ettiği Birleşmiş Milletlerin kentleşme değerlendirmelerinde yer almaktadır. Kentlerin ihtiyaçlarını; yüz ölçümleri, demografik geçişler, küresel ısınma, yeni kent sakinlerinin gelişen ve değişen talepleri gibi birçok faktör şekillendirmektedir. Sınırlı kaynaklarla hergün değiş̧en ve hızla artan bu ihtiyaçların sürdürülebilir bir biçimde karşılanması ancak yenilikçi ve akıllı çözümlerle mümkün görünmektedir (Deloitte, 2016:10).

21. yüzyılın en önemli zorlukları olarak sıralanan küreselleşme, şehirleşme ve iklim değişiklikleri acil ve etkili çözüm beklemektedir (Komninos, 2015:1). Bu yüzden akıllı kentlerin temel hedefi teknolojiyi en iyi şekilde kullanıp, ihtiyaç halinde yeni teknolojiler üretip ve üretilen teknolojilerin birbirleriyle uyumlu ve düzenli çalışmasını sağlayarak bu zorluklardan kaynaklanan hızlı nüfus artışı ve kaynak kıtlığı tehditleriyle mücadele etmektir (Herzberg, 2017:25).

18. yüzyılda dünya nüfusunun büyük bölümü tarımla uğraşmaktaydı ve kentlerde yaşayan insanlar küresel nüfusun ancak \%5'ni meydana getirmekteydi. Kentlerin cazibesi, kaliteli bir yaşam, daha iyi eğitim, sağl1k hizmetlerine daha kolay erişim ve daha fazla iş imkânı gibi beklentilerin etkisi ile 20. yüzyılda kentlere göç kontrol edilemez bir hıza ulaşmıştır. Bugün dünya nüfusunun \%50'sinden fazlası kentlerde yaşamakta ve bu yüzyılın sonlarına doğru bu oranın \%80'den fazla olacağı tahmin edilmektedir (Harrison ve Donnelly, 2011:2). Kentlerdeki yaşanan hızlı nüfus artışı beraberinde ulaşım, enerji, su, sağlık, çevre ve güvenlik gibi alanlarda birçok sorunu tetiklemektedir. Ortaya çıan bu sorunlar kentlerdeki ekonomik ve sosyal hayatı olumsuz yönde etkilediği gibi, kentlerde yaşayanların yaşam kalitesini düşürerek, kentlerin marka ve rekabet gücünü büyük ölçüde zayıflatmaktadır (McKinsey, 2013:9). Bu türden problemlere çözüm bulmak amacıyla ortaya çıkan "akıllı kent" yaklaşımı, kentlerde yaşayanların hayat standartlarını yükseltmek için geleneksel politikaları terk edip, bilgi ve iletişim teknolojilerinin sunmuş olduğu firsatları toplumsal yaşamla bütünleştirdiği için dünyada ve Türkiye'de hızla yaygınlaşmaktadır (Akdamar, 2017:46). Akıllı kentlerin, teknolojik yeniliklerin yanında başarılı olabilmesi; sürdürülebilir enerji kaynaklarına, yeterli yeşil alana, yeterli tarım arazisine ve su kaynağına sahip olması, katılımcı ve şeffaf bir yönetimi benimsemesi ile doğru orantılıdır (Çelikyay, 2008:1323-1324).

Nüfus artışı, ulaşım, kirlilik, sürdürülebilirlik, güvenlik, sağlık ve iş dünyası gibi toplumdaki en büyük sorunlara çözüm aramanın bir yolu olarak akıllı kentler sunulmaktadır (Abella ve De-Pablos-Heredero, 2015:839). Akı1lı kentler, kentin zekasını sürdüren akıllı bilgi ve iletişim teknolojilerinin; ağlar, sensörler, akıllı yönetim sistemleri (Akdamar, 2017:46), akıllı telefonlar, mobil cihazlar, gömülü sistemler, akıllı ortamlar, akıllı sayaçlar (Schaffers vd., 2011:434) gibi teknolojilerin desteğiyle insan, doğa ve finansal kaynakların etkin kullanımını sağlayarak maliyet tasarrufunu teşvik etmektedirler (Deloitte, 2016:5).

İngilizce "Smart Cities" ifadesinin karşıllğı olan akıllı kent kavramı literatürde tercihen kullanılsa da dijital, bilişim ve bilgi (Kes Erkul, 2017:1) kentleri kavramlarına da literatürde rastlanılmaktadır (Alkan, 2015:72). Literatürde bazı yazarlar akıllı kenti; kentin kollektif zekâsını kullanmak için fiziksel, sosyal, bilgi iletişim teknolojileri ve altyapılarının birbirine bağlanması (Harrison vd., 2010:2) olarak tanımlarken, bazı yazarlar ise akıllı kenti; ekonomi, yönetişim, insan, mobilite, çevre ve yaşam algılarında geleceğe yönelik öz-kararl1, bağımsız ve farkında vatandaşların, bağış ve faaliyetlerin akıllı birleşimi (Gülseçen vd., 2013:226) ve bileşenlerle bağl1 kompleks bir sistem olarak tanımlayabilmektedir (Bennett vd., 1996:3).

Akı1lı kent kavramı ilk olarak, sürekli yeniliği desteklemek, sorunları ya da zorlukları çözmek için ihtiyaç duyulan "yüksek entelektüel ya da beşeri sermaye" ile karakterize edilmektedir. İkinci olarak, hedefler açısından, akıllı kentler sosyal içermeyi, önemli ölçüde iyileştirilmiş yaşam kalitesini ve ekonomik kalkınmayı ve son olarak da, akı1lı kent politikaları aynı zamanda yaşam boyu öğrenme, doğal kaynakların optimal yönetimi 
ve genel olarak sürdürülebilir kentsel kalkınma yoluyla beşeri sermayenin geliştirilmesini kapsayan üç temel özelliği ön plana çıkaran bir konsept olarak karşımıza çıkmaktadır (Ojo ve diğerleri, 2016:30). Ayrıca, akıllı kent: (i) ekonomik ve politik etkinliği artırmak ve bilgi iletişim teknolojisi de dahil olmak üzere sosyal, kültürel ve kentsel kalkınma altyapılarını sağlamak için ağa bağlı altyapıların kullanılması; (ii) iş başında kentsel gelişme; ve (iii) sosyal ve çevresel sürdürülebilirlik gibi üç öğe ile de karakterize edilmektedir. Sosyal sürdürülebilirlik sosyal uyum ve aidiyet duygusu anlamına gelirken, çevresel sürdürülebilirlik kentsel büyüme ve gelişmenin ekolojik ve "yeșil" etkilerini ifade eder (Hollands, 2008:307-308). Bu anlamda, akıllı kent platformları kentsel sürdürülebilir kalkınma konusundaki sinerji ve işlevselliklerini hizmet ve metodolojileri açısından güvence altına almak üzere kurulmuştur ve kapsamı, genel olarak, vatandaşların yaşam kalitelerini artırmak, herkese sosyo-ekonomik fırsatlar sunmak için daha akıllı ve daha yeşil olma girişimlerine karşıllk gelmektedir.

Hall (2000) akıllı kenti, kentin kaynaklarının en iyi biçimde kullanılmasını sağlamak için yollar, köprüler, tüneller, tren yolları, metrolar, iletişim, su, enerji ve önemli binalar gibi altyapıların durumlarının izlenip sistemlerinin bütünleştirilmesi olarak tanımlamaktadır (Hall, 2000:1'den akt. Gül ve Atak Çobanoğlu, 2017:1546).

Ak1llı kent tanımlamalarında, etkin kentsel hizmetler ve verimli kent sistemleri (Goodspeed, 2015:83) ana temaları çerçevesinde iki önemli nitelik göze çarpmaktadır. İlk olarak, kentsel alt sistemlerin parçalarının birleştirilmesi ve koordinasyonunda teknoloji kullanılarak ekonomik gelişme, servet oluşturma ve yeni iş imkanları için daha akıllı çözümler getiren ortam olmaları ve ikinci nitelik olarak da daha fütüristtik bir tanımla, yaşanmış tecrübelerin yeni gerçekliği -çoklu konsept- (Komninos, 2015:19) çağrıştıran kentsel mekanlar olmalarıdır (Glasmeier ve Christopherson, 2015:6).

Sonuç olarak akıllı kentler, hızlı nüfus artışı nedeniyle çıkan birçok sorun ve talebin karşılanabilmesi için sınırlı kaynakların, bilgi ve iletişim teknolojilerinin desteği ve vatandaşların katılımı ile akıllı kombinasyonlar yaparak etkin ve verimli kullanılması olarak tanımlanabilir.

Akıllı kent yaklaşımı temelde "insan", "kollektivite" ve "yapay zekâ" olmak üzere üç boyuta sahiptir (Komninos, 2008:122). Ancak akıllı kentlerin gelişimine katkı sağlayan; "akıllı vatandaş, akıll yönetişim, akıllı ekonomi, akıllı hareketlilik, akıllı çevre ve akıllı yaşam" gibi altı ana unsur bulunmaktadır (Giffinger, 2007:12):

- Akıllı Vatandaş: Akıllı kentin en önemli aktörü olarak vatandaşların akıllı, bilinçli ve kaliteli sosyal sermayeye sahip olmaları gerekir. Yeterlilik seviyesi, hayatboyu öğrenme eğilimi, toplumsal ve etnik çeşitlilik, esneklik, yaratıcılık, açık fikirlilik ve toplumsal yaşama katılım akı1lı vatandaş bileşeninin özellikleri arasında değerlendirilmektedir (Giffinger ve Gudrun, 2010:708). Akıllı kent uygulamalarında akıllı insan veya akıllı vatandaş kavramının odak noktası olduğu ve akıllı vatandaş olmadan akıllı kentlerin olamayacağı ve başarıya ulaşamayacağı da unutulmamalıdır (Örselli, Bilici ve Babahanoğlu, 2018: 8).

- Akıllı Yönetişim: Akı1lı vatandaşa sahip kentin; devletin ve belediyelerin akıllı kentler konusundaki kurumsal kapasiteleri ve bilinç düzeyleri, geliştirdikleri planlar, politikalar, e-yönetim uygulamaları, kent sakinlerinin karar alma süreçlerine katılımı (Vanola, 2014:887), bu kapsamda geliştirilen mobil uygulamalar ve online sistemlerini (Varol, 2017:53) kapsayan akıllı yönetişimi de benimsemesi gerekir. Akıllı kentlerin yürütücüleri ve paydaşları şunlardır: Merkezi hükümet, bölgesel ve yerel yönetimler; kent sakinleri ve sivil toplum kuruluşları; uluslararası birlikler ve organizasyonlar; üniversite ve araştırma merkezi gibi akademik girişimler; büyük uluslararası şirketler ve girişimciler; yatırımcılar ve finans kuruluşları; çıkar grupları ve kişilerdir (Gürsoy, 2019: 59). Bir akıllı kent girişiminin istenilen sonuçlara ulaşabilmesi ve toplumun geniş bir kesimine hitap edebilmesi için işbirliği ve karar alma süreçlerine katılım gibi ilke ve standartlara dayalı (Lee ve diğerleri, 2014:89) akıllı yönetişim kanallarını geliştirmesi gerekir. İşbirliği ve karar alma sürecine katılıma ilave olarak veri paylaşımı, kamusal ve sosyal hizmet ve uygulamaların bütünleştirilmesi, hesapverebilirlik, şeffaflık (Biçakcı, 2014:27), politik stratejiler ve perspektifler de (Giffinger ve Gudrun, 2010:14-15) akı1lı yönetişime derinlik katmaktadır. Özet olarak karar verme sürecine katılım, kamusal ve sosyal servisler, şeffaf yönetim e-demokrasi anlayışını yansıtan politika stratejileri ve perspektifler (Velibeyoğlu, 2019:8) akıllı yönetişimin özünü meydana getirmektedir.

- Akıllı Ekonomi: Akıllı ekonomi, yerel ve küresel ekonomik ağlarla bütünleşmenin yanısıra ekonomik rekabet edebilirlik kapsamında girişimcilik, yenilikçilik, ekonomik imaj, markalaşma, verimlilik, işgücü piyasasının esnekliği (Chourabi ve diğerleri, 2012:2293), uluslararası yerleşmişlik, değişebilme ve dönüşebilme yeteneği ve iş piyasalarının esnekliğini de kapsamaktadır (Giffinger ve Gudrun, 2010:14). 
Yani akıllı yönetişimi benimseyen kentin akıllı olarak nitelendirilebilmesi için ekonomisinin de akıllı olarak yönetilmesi gereklidir. Yukarıda sayılan şartların sağlanabilmesi için yapılacak olan projelerin ve programların ek finansman ihtiyacı tüm ülkeler için en temel zorlukların başında gelmektedir. Doğru ekonomik modeller ve teknolojiler uygulanırsa kaldıraç etkisiyle mevcut kaynaklar daha etkin kullanılabilecek, finansmana, insan kaynağına veya zamana dair sıkıntılar aşılabilecektir (Deloitte, 2016:12).

- Akıllı Hareketlilik/Mobilite: Akıllı hareketlilik kavramı özet olarak bilgi ve iletişim teknolojileri destekli nakliye ve lojistik hizmetlerini kapsamaktadır (Bilici ve Babahanoğlu, 2018:131). Akıllı ekonominin zaman ve mekan açısından başarıya ulaşabilmesi için; kentteki ulaşım sistemleri, trafik yönetimi, yoğunluk ölçümü, trafik yönlendirme, akıllı kavşak, akıllı durak, akıllı parkmetreler, park yönlendirme, toplu taşımada bütünleşik ücret ödemesi, GPS takip, yol sensörü, ileri yolcu bilgi sistemlerini içeren düzeneklerin (Varol, 2017:54) sisteme entegre edildiği iyi çalışan bir akıllı hareketlilik/mobilite sistemine ihtiyaç duyulmaktadır. Yerel erişebilirlik, ulusal ve uluslararası erişebilirlik, BİT altyapısı, sürdürülebilir, yenilikçi ve güvenli nakliye ağı (Giffinger ve Gudrun, 2010:14-15) akı1lı hareketliliğin düzeyini göstermektedir. Akıllı hareketlilik öncelikli olarak çevre dostu ve özellikle dezavantajlı gruplar için kapsayıcı ulaşım çözümleri getirmeyi amaçlamaktadır (Elvan, 2017:7).

- Akıllı Çevre: Akıllı hareketlilik/mobilite sağlanırken çevreninde gözardı edilmemesi için akıllı düzenlenmesi ve düzenli olarak kontrol edilmesi çok önemlidir. Akıllı çevre kapsamında; altyapı otomasyonu, su ve kanalizasyon sistemleri takibi, katı atık toplama/ayrıştırma sistemleri, çevre kalitesi ölçümü, enerji tüketimi azaltma gibi uygulamalar yer almaktadır (Varol, 2017:54). Kirlilik, çevresel koruma, sürdürülebilir kaynak yönetimi konularında gelişimin ve sürüdürülebilirliğin sağlanması (Giffinger ve Gudrun, 2010:14-15), yeşil alanlar ve su kaynaklarının kontrolü teknoloji yardımıyla daha kolay hale gelmektedir (Deloitte, 2016:12). Kirlilik oranlarının azaltılması ve çevrenin korunması sayesinde kentin doğal güzelliklerinin arttırılması hedeflenir (Bilici ve Babahanoğlu, 2018:132).

- Akıllı Yaşam: Yukarıdaki unsurları sağlayan akıllı kentlerin temel hedeflerine ulaşabilmesi için akıllı yaşam vazgeçilmez bir unsuru olarak karşımıza çıkmaktadır. Akıllı yaşam; kamu güvenliği, suçla mücadele (kamera ya da sesli takip sistemleri), kentsel acil müdahale ve denetleme, afet yönetimi, itfaiye, sağlık ve eğitim hizmetleri, kültür ve turizm hizmetlerinde iletişim/yönlendirme gibi uygulamaları içermektedir (Varol, 2017:55).

Akıllı şehirlerin temel altyapısını kentsel teknolojiler meydana getirmektedir. Kentin gerçek zamanlı analizi ve değerlendirmesinde coğrafi bilgi sistemleri, sanal gerçeklik ve simülasyon teknolojileri ciddi bir paya sahiptir (Velibeyoğlu, 2019:2). Eski kentler, kullanılan cam ve metal oranları ile değerlendirilirken, günümüzde akıllı kentler bilgisayar, donanım ve internet altyapıları ile değerlendirilmeye başlanmış (Tawnsend, 2013:XII), bu bağlamda kentlerin akıllı olarak nitelendirilebilmesi ve akıllılık düzeyinin ölçülebilmesi için artık "mobil cihazlar, dijital platformlar, nesnelerin interneti, büyük veri, açık veri, bulut bilişim" gibi teknolojiler kullanılmaktadır. Kentsel teknolojiler kimi zaman eskinin yerini alma, kimi zaman yeni düşünceleri tetikleme ve kimi zaman ise var olanı zenginleştirme şeklinde bir etki yapmaktadır. Bu teknolojiler aşağıdaki gibi özetlenebilir:

- Mobil Cihazlar: Kişisel bilgisayarlar, tablet bilgisayarlar, akıllı telefonlar, kiosklar, akıllı sayaçlar ve internet merkezleri gibi cihazlar ve platformlar akıllı kent hizmetlerinin kentliler tarafindan kullanımının yaygınlaştırılması için çok büyük öneme sahiptirler (Kes Erkul, 2017:2). Kullanıcıların tercihini yansıtan ve kişisel bilgilerini taşıyan bu mobil cihazlar, konum tabanlı hizmetler ve içeriği zenginleştirilmiş servisler ile akıllı şehir çözümlerine erişim konusunda önemli bir yere sahiptir (Deloitte, 2016:13).

- Dijital Platformlar: Barınma, iş, ulaşım ve içilebilir suyun güvenli dağıtımı birçok kentin acil çözüm bekleyen başlıca sorunları arasında gelmektedir. Yeni nesil altyapılar elektriklendirme, otomasyon ve dijitalleştirmeyi merkezine alarak çözüm aramaktadır (Dijital Ekosistem.., 2017). Bu yüzden dijital platformlar, pratik ve düşük maliyetli çözümler sunarak arz ve talebin buluşmasını ve katılımın artmasını sağlayan sanal mecralardır.

- Nesnelerin İnterneti: Akıllı kent uygulamalarının kapsadığı kentsel unsurların, entegre edilen sensörlerle akıllı araçlara dönüşmesi ve birbirleri ile iletişime geçerek (Kökciyan ve Yolum, 2017:1) bilgi toplamaları ve bunları paylaşmaları nesnelerin interneti (IoT) olarak değerlendirilmektedir (Kes Erkul, 2017:2). Yani sensör ve kablosuz internet bağlantısının eşyalarda kullanılmasıdır. Nesnelerin İnterneti işbirliği ile oluşturulan varlıklara oyun değiştirici bir platform olarak imkân tanınmaktadır. Özelikle verimlilikteki 
artış ve yaşam kalitesindeki yükseliş hızının bölgedeki nüfusun eğitim düzeyiyle doğru orantılı olduğu ifade edilmektedir (Shapiro, 2006:325). Nesnelerin internetinin sahada uygulanma örneklerinin başında, kentlerdeki ulaşım hatlarında makineden makineye (M2M) bağlı sistemlerin kullanılarak daha akıllı ulaşım sistemlerinin oluşturulması örnek olarak gösterilmektedir (Akı1lı Kentlerin Temel Taşı, 2017).

- Büyük Veri: İnternet ortamında yapılan e-ticaret, mesajlaşma, konum paylaşımı, e-uygulamalar, algılayıcı cihazlar aracılı̆̆ıyla yapılan her türü etkileşim ve iletişim, kullanıcıları farkında veya farkında olmadan yüksek hacimlerde veriyi dijital olarak üretmekte ve kaydetmektedir. Yani hızla yenilenen teknolojiyle birlikte hemen hemen herkes, herşey, her etkileşim ve iletişim dijital bir iz bırakmaktadır (McKinsey, 2013:9). A $\breve{g}$ sensörleri, akıllı objeler ve cihazlar, web ve sosyal medya gibi modern bilgi ve iletişim teknolojileri tarafından yakalanan ve kaydedilen düzenlenmiş ve düzenlenmemiş herşey büyük veriyi oluşturmaktadır (Rabari ve Storper, 2015:28). Bu büyük verinin depolanması ve işlenmesi, akıllı kent platformunun önemli bir ayağını oluşturmaktadır (Kes Erkul, 2017:3). Büyük veri, şehirlerin nasıl işlediği konusundaki deneyimleri zenginleştirmekte ve sosyal etkileşim için daha fazla bilgiye dayalı karar verme firsatı sunarak şehirlerde en iyi nasıl etkileşim kurulabileceğine dair bilgiler sunmaktadır (Batty, 2013:277). Ak1llı sistemlerin akıllı çözümler üretmesinin yolu, hergün binlerce sensörden toplanan "Büyük Veri"nin akıllı süreçlerden geçerek kent halkına ve yöneticilerine katma değerli bir bilgiye dönüşmesidir (İsbak, 2017).

- Açık Veri: Herkes tarafından ücretsiz ve serbest bir şekilde kullanılan, herhangi bir telif hakkı, patent ya da diğer kontrol mekanizmalarına tabi olmayan veri "açık veri" olarak tanımlanmaktadır (Akdamar, 2017:46). Bilgisayarca okunabilen, herkesçe kullanılabilen ve yeniden yayınlanabilen açık veri kamu dahil pekçok sektördeki rekabeti ve yapılan işlerin kalitesini artırmaktadır (Deloitte, 2016:34).

- Bulut Bilişim Teknolojisi: Her geçen gün daha fazla çeşitlilikte ve büyüklükte veri üretilmektedir. Özellikle günümüz teknolojisindeki mevcut cihazlarda kullanıcılar her geçen gün daha fazla kişisel veri ve data saklamak istediği için depolama kapasitesi büyük sorunlara sebep olmaktadır. $\mathrm{Bu}$ sorunlara çözüm olarak ortaya çıkan Bulut (Cloud) Teknolojisi, internet üzerinden, erişimde bulunulan yazılım uygulamaları, veri depolama hizmeti ve işlem kapasitesi olarak tanımlanmaktadır. En düşük kapasiteli cihazla bile istenilen yerden istenildiği zaman her tür bilgiye, kişisel veriye ulaşılması mümkün olmaktadır. Tüm bu işlemler için, dijital bir ağ aracılığıyla çoklu sunucu bağlantısı gerçekleştirilmesi yeterlidir. Bulut bilişim fikrinin temelleri 1950'li yıllarda atılmıştır. İnternet devlerinden olan Amazon, veri merkezlerini modernize ederek bulut bilişimin gelişmesinde anahtar bir rol oynayarak ilk gerçek bulut bilişim hizmeti olan Amazon S3'ün 2006 yılında hizmete girmesini sağladı (Bulut, 2018). Bulut Bilişim Teknolojisi veri depolama hizmetine getirilen kablosuz ve rasyonel etkili bir çözüm olarak değerlendirilmektedir.

\section{DÜNYADAKİ ETKİN AKILLI KENT UYGULAMALARI}

Küreselleşmenin etkisi ile 21. yüzyıl kent yaşamının tüm pratiklerinde hızlı bir değişim yaşanmış ve ülkeler hatta kentler arasında ekonomik, sosyal, yönetsel ve kültürel alanda işbirliği ve bütünleşmeler görülmüştür. Bilgi iletişim teknolojilerindeki hızlı gelişmelerin neden olduğu bilgi çağı, yeni bir kültürün doğmasına sebep olmuş ve kentsel mekânda, üretim, yapılaşma, ulaşım ve iletişim gibi birçok alanda kentsel hayatı kolaylaştıran ve zaman tasarrufu sağlayan olanaklar ortaya çıkmış (Velioğlu, 2019:1) ve akıllı kent düşüncesinin yaygınlaşmasında çok etkili bir faktör olmuştur. Bu bağlamda teknolojiyi kent yaşamıyla birleştirebilen, onu adapte edebilen kentler hızla akıllı bir forma dönüşerek kentsel mekânlardaki yaşam kalitelerinin artmasına ve daha sürdürülebilir bir kent yaşamına imkân tanımaktadır. Bu doğrultuda dünyada birçok kentte akıllı uygulamalar hızla yaygınlaşarak, her geçen gün yeni projeler hayata geçirilmeye devam etmektedir. Çalışmanın bu bölümünde dünyada bazı akıllı kent uygulamalarından örnekler verilmeye çalışılmaktadır.

Sürdürürlebilirlik ve yaşam kalitesi konularında 10 ana başlıkta toplam 83 göstergeyi dikkate alarak sıralama yapan IESE Cities'in 2018 yılında yayınladığı Motion Index 2018 akıllı kentler sıralamasına göre New York (1), Londra (2), Paris (3) 2017'de olduğu gibi sıralamadaki yerlerini korumuş ve listenin devamı Tokyo (4), Reykjavik (5), Singapore (6), Seoul (7), Toronto (8), Hong Kong (9) and Amsterdam (10) şeklinde kısmen değişmiştir (Cities In Motion, 2018).

Kentler için yeni bakış açısı getiren "Akıllı Büyüme" (1998) hareketi, akıllı kent fikrinin çıkış noktası olarak değerlendirilmektedir. Portland ve Oregon akıllı büyümenin yaygın bir örneği olarak kabul edilmektedir (Harrison ve Donnelly, 2011:2). Bunun yanında Güney Kore'deki Songdo ve Suudi Arabistan'daki Kral 
Abdullah Ekonomik Şehri gibi bazı akıllı kentler şehir hizmetlerinin internet üzerinden yürütülmenin ilk test edildiği yerlerdir (Herzberg, 2017:24). Güney Kore'de inşa edilen Songdo akıllı kentinde; yollara, elektirik şebekesine, su ve atık sistemlerine yerleştirilen milyonlarca sensörle dünyanın en büyük şehir otomasyon uygulaması gerçekleştirilmiştir (Tawnsend, 2013:24).

Chicago ve Singapur, kentin işleyişini takip edebilmek için kentin birçok noktasına sensörler yerleştirmektedir. Seoul 5G'yi kullanan ilk ak1ll kenttir (Dijital Ekosistem.., 2017). New York, Londra, Paris, Barselona, Amsterdam, Berlin, Manchester, Edinburgh, Hamburg, Guayaquil ve Bath gibi pek çok kent akıllı kent stratejilerini caddelerine, kamu hizmetlerine, eğitime ve sağlık altyapısına akıllı uygulamalar ekleyerek ve yeni bölgeler kurup, kurulan bu bölgelerde dijital hizmetlerin tamamını vererek, kademeli olarak daha akıllı hale gelmeye çalışmaktadır (Herzberg, 2017:21). Bu uygulamalar içinde; toplu taşıma uygulamalarında kullanılabilen çok fonksiyonlu akıllı kartlar, akıllı vatandaşlık kartları, dijital yetenek öğretim programları, eyönetim uygulamaları gibi akıllı uygulamalar yer almaktadır.

Hangzhou, Barcelona ve Singapur trafiği yönlendirmek, aydınlatmayı kontrol etmek ve etkin atık yönetimi için sitemlerinde yapay zekâdan faydalanmaktadırlar. Yapay zeka ve büyük veri analiz yeteneklerini kullanarak, tüm araçlar izlenebilmekte, video ve resim tanıma teknolojilerine dayalı gerçek zamanlı trafik önerileri ve seyahat güzergahları verilebilmekte, trafik tıkanıklığının azalması, trafik kazalarının otomatik olarak algılanması ve park etmenin yasak olduğu yerlerin gerçek zamanlı olarak izlenmesi sağlanmaktadır. Sistem, kaza, durdurma veya park ihlallerini anında tespit edip polise otomatik olarak haber verilebilme özelliğine sahiptir (NTBOX Magazin, 2017).

New York kentinde telefon kulübeleri; haberleri izlemek, yakınlardaki indirimli alışveriş firsatlarından haberdar olmak ve kablosuz internet imkânları ile adeta bilgi merkezleri haline getirilerek vatandaşların hizmetine sunulmuştur (Akıllı Kent Yönetim Sistemleri, 2017).

Los Angeles'ta akıllı ulaşım sistemleri ile duraklamalarda \%35, kavşaklardaki beklemelerde \%20, seyahat süresinde \%13 azalma ve bunlara bağlı olarak yakıt tüketiminde yaklaşık \%13 azalma sağlanmıştır. Akıllı sokak aydınlatması sistemiyle Oslo'daki elektrik tüketimi tasarruf oranı \%70 düzeyindedir. Analiz Yoluyla Önceden Suç Tespiti Sistemi sayesinde hırsızlık oranlarında \%19 azalma sağlanmıştır (Deloitte, 2016:10).

Özellikle son zamanlarda ekoloji ve akıllı kent birlikte düşünülmekte ve yüksek teknolojiye sahip ülkeler tarafından birçok yerde eko-akıllı kent denemeleri yapılmaktadır. Örneğin, Tokyo'nun bir banliyösünde kurulan eko-akıllı kentte karbondioksit oranı sıfırdır. Kentte elektrik tüketiminin olduğu her yerde yüksek verimli cihazlar kullanılmaktadır. Sokak ve ev aydınlatmasında \%100 led ampul kullanılmaktadır. Evler hava durumuna göre 1sıtılmakta ve soğutulmaktadır (Ak1llı Şehirler için.., 2017).

Amsterdam'da kentte bulunan otoparklardaki boş park yerlerinin izlenip kiralanması için "Mobypark" adlı akıllı telefon uygulaması başarılı olarak kullanılmaktadır (Akıllı Kent Yönetim Sistemleri, 2017). Amsterdam Schiphol Havalimanı şehrin kanalizasyon atıkları sayesinde 1sınmakta, stadyuma yerleştirilen güneş panelleri sayesinde de stadyumun enerji ihtiyacı karşılanmakta ayrıca yerel bir hastane çatısına yerleştirilen güneş panelleri hastanenin enerji ihtiyacını karşılayarak, elde ettikleri ekstra enerjiyi de etraftaki evlere kullandırmaktadırlar (ASÜD, 2017). Binalarda güneş enerji panelleri vasıtasıyla elde edilen enerji gece kullanılmak üzere depolanarak şehir şebekesine aktarılmaktadır (Şenol, 2017:52). Ayrıca Amsterdam'ın I Amsterdam City Card projesi kapsamında online bir kart ile kentte ücretsiz şekilde ulaşım, müzelere giriş, kanal gezisi yapılabilmekte ve ayrıntıl bir kent haritasından faydalanılabilmektedir. Bu kart Amsterdam kenti içerisinde restoranlar, konserler, tiyatrolar ve araç kiralamalarında büyük indirim firsatı sunmaktadır (Gül ve Atak Çobanoğlu, 2017:1554).

Diğer taraftan, en yeni hız kameraları kullanılarak insan davranışındaki kalıpların veri analitiği yapılarak kentte hız yapanların yakalanması, yalnız yaşayan yaşlıları izlemek için evlerine hareketli sensörler yerleştirilmesi, hareket durduğunda, yaşlı kişinin kontrol edilmesi için sağlık kuruluşuna bilgi aktarılması gibi birçok uygulamalarla Singapur, akıllı kent teknolojisinde küresel bir lider olma yolunda büyük adımlar atmaktadır (NTBOX Magazin, 2017). Yaşlılara ve engellilere dağıtılan özel kartlar sayesinde, yaya geçitlerinde karşıdan karşıya geçişlerinde trafik ışıklarının daha uzun süre yanması sağlanmıştır (Xsights, 2016:32). 2014 yılında yürürlüğe giren Smart Nation programı kapsamında Singapur'un gerekli görülen her yerine yerleştirilecek olan sensör ve kameralar sayesinde toplanacak verilerle şehir devleti içerisindeki halka açık alanların temizliğinden kayıtlı tüm araçların çizdikleri rotalara kadar herşey izlenebilecek ve kuralları ihlal edenler takip edilebilecek, patlama vb. durumda toplumun davranışları ve bulaşıcı hastalıkların nasıl yayıldığı analiz edilebilecektir. Verilerin büyük bir çoğunluğu Virtual Singapore adı verilen devlete ait bir platformda saklanacak ve gerektiğinde özel sektör ile paylaşılabilecektir (Singapur: Akıllı Kentlerde.., 2017). 
2025 yılında karbon salınımını sıfırlayan ilk başkent olmayı hedefleyen Kopenhag, en düşük karbon salınımına sahip büyük kentlerden birisidir (Kamp, 2015:137). Bu şehirde ev-iş arası düzenli yolculukların \%40'1 bisikletlerle yapılmaktadır. E-bisiklet uygulaması sayesinde trafik ve hava kalitesine ilişkin gerçek zamanlı veriler toplanmakta ve toplanan veriler paylaşılmaktadır (Özhaseki, 2018:26). Kopenhag tüm kente wifi bağlantısı sağlayarak City Wifi projesini başlatmıştır. Sağlik ve belediye hizmetleri için akıllı uygulamalar geliştirilmiştir. Ayrıca Smart Parking projesi ile park yerlerinde sensörler kullanılarak akıllı telefon uygulamalarıyla sürücülere hızlıca açık park yeri tanımlanıp kentin önemli bölgelerinde trafik yoğunluğu azaltılmaktadır. Bunun yanında Smart Water ve Smart Waste projeleri ile sel baskınlarının önlenmesi ve çöp konteynırlarının doluluk oranlarının tesbiti yapılarak hem çevreci hem de maliyet azaltıcı uygulamalar hayata geçirilmiştir (Gül ve Atak Çobanoğlu, 2017:1553).

Avrupa Birliği, akıllı kent yatırımları konusunda birçok finansal destek sağlamaktadır. Bu yüzden 43, 44, 45 nolu eylem planları ve 7. Çerçeve Programı ile akı1lı kentler konusunu gündeme getirilmiş (Vanolo, 2014:891892) ve birçok platformda da gündem yapılmaya devam edilmektedir. Avrupa'da önemli şehirlerin üyesi olduğu EUROCITIES tarafından da akıllı kentler için, en düşük enerji kullanımı ile en yaşanabilir çevreyi sunabilme teması ön plana çıkarılmaktadır. Özellikle akıllı elektrik şebekeleri ve akıllı binalar bu alandaki önemli gelişmelerdir. AB'de tüketilen elektriğin \%40'dan fazlası binaların aydınlatma, 1sıtma ve soğutmasında kullanılmaktadır. $\mathrm{AB}$ tarafindan topluluk programları kapsamında desteklenen akıllı bina pilot projelerinden \%20 enerji tasarrufu sağlandığı görülmüştür (Çerçi, 2015:197-198).

\section{AKILLI KENT EĞİLIMININ TÜRKIYE KENT UYGULAMALARINA YANSIMALARI}

Yenilikçiliğin ana kaynağı olarak görülen kent yaşantısı talebinin özellikle 2000'lerden sonra biçim değiştirmesi sonucu kentleşme oranının ülkemizde de hızla artması, trafik, yapılaşma, hava kirliliği, eğitim, sağlık, güvenlik, iletişim, altyapı, enerji, çevre ve işsizlik gibi birçok sorunu da beraberinde getirmektedir (Çelikyay, 2008:1321). $\mathrm{Bu}$ sorunların çözülerek yaşam kalitesinin arttırılması ve hizmetlerin iyileştirilmesi ancak bilgi ve iletişim teknolojileri destekli çözümlerle mümkün görünmektedir. Türkiye'de akıllı kentler konusunda merkezi idareler ve yerel yönetimlerin coğrafi bilgi sistemleri tabanlı bazı çalışmaları olmakla birlikte, bu konuda henüz kapsamlı hedefler belirlenmemiştir. Ancak özellikle büyük şehirlerde kentsel hizmetler, ulaşım, enerji ve su hizmetleri gibi kısmi alanlarda akıllı kent çözümlerine başlandığı görülmektedir.

Bununla birlikte Türkiye'de 2000'li yıllardan itibaren, gerek kalkınma planları ve programlarında, gerekse farklı politika ve strateji belgelerinde akıllı kentlere ilişkin bazı hedeflerin belirlendiği görülmektedir. 10. Kalkınma Planı, Y1llık Programlar, Ulusal Bilim ve Teknoloji Politikaları, 2003-2023 Strateji Belgesi-Vizyon 2023, Bilgi Toplumu Stratejisi ve Eylem Planları en çok dikkat çekenlerdir. Akıllı Belediyecilik Zirveleri, Akıllı Şehirler Kurultay1, Akıllı Şehirlere Dönüşüm Hareketi Projesi, Akıllı Kent Fuarı ve Akıllı Kentler Otomasyon Sistemi kamu ve özel sektörü bir araya getiren oluşumlardan bazılarıdır (Varol, 2017:47).

2000 yılı başlarında Yalova'da başlatılan bir eko-tech yerleşim yerinin kurulması projesi, Türkiye'nin ilk akıllı kent uygulaması olarak kabul edilen Bilişim Vadisi Projesi'dir. Bu uygulamanın ardından Bursa, Kocaeli, Ankara başta olmak üzere başka kentler tarafından da Bilişim Vadisi Projeleri gündeme alınmaya başlanmıştır. Ayrıca Fatih ve Beyoğlu belediyelerinin GoogleEart programı ile uyumlu çalışan üç boyutlu sokak görüntüleme gibi belediye bazlı projelere de rastlamak mümkündür (Xsights, 2016:38). Ancak bütün olarak bir kent hizmetlerini yönetme çözümü olarak hazırlanan ilk akıllı kent projesi Karaman ilimizde başlatılmıştır. Sensörler, nesnelerin interneti bileşenleri, altyapı, kiosklar, dokunmatik ekranlar, bilgilendirme ekranları, toplu mesaj sistemleri, akıllı park ve TEDES, veri merkezi ve operasyon merkezi (Mangır, 2016:27) ile birbirine entegre 20 uygulama ile şehir yaşamındaki tüm süreçlerde verimlilik yaşanacaktır.

Akıllı sulama, akıllı aydınlatma, akıllı sayaç okuma sistemleri ile su ve enerji kaynakları verimli kullanılarak kentin sürdürülebilirliğinin sağlanması planlanmakta; böylece hizmet kalitesinde artış sağlanarak, belediye ile vatandaşlar arasındaki iletişim güçlendirilmeye çalışılmaktadır (Türk Telekom, 2018). Akıllı Kent Otomasyon Sistemi (AKOS) projesiyle, kent ve kentli ile ilgili bilgilerin adres ve taşınmaz tabanlı olarak yerinde tespit edilmesi sonucunda bilgiye dayalı yönetim anlayışı ve katılımcı belediyecilik hedeflenmiştir (Akıllı Kentler Nedir?, 2017). Belli başlı büyükşehirlerimizin akıllı kent kapsamında ortak noktaları olarak veri analiz merkezi, coğrafi bilgi sistemi (CBS), trafik kontrol merkezi, GPS ile araç takip sistemi, atık yönetimi, wifi, merkezi haberleşme, navigasyon, güvenlik kameraları ve kısmen yenilenebilir enerji projelerinden bahsetmek mümkündür. 
İstanbul Büyükşehir Belediyesi tarafından akıllı kent projeleri kapsamında, daha hızlı ve kesintisiz hizmet verebilmek için uluslarası standartlarda veri analiz merkezi kurulmuştur (IBB, 2017). Araç üzeri IoT'yi birleştiren atık yönetiminin yapıldığı Çevre Kontrol Merkezi, İstanbul'un 610 kamera ile izlendiği Trafik Kontrol Merkezi, mobil trafik verilerinin paylaşıldığı ve online navigasyon sağlayan İBB NAVİ, ortak kullanımlı telsiz hizmetleri (OKTH), akıllı kent mobilyaları ile iletişim yer almaktadır. Birçok akıllı ulaşım uygulaması, akıllı otopark sistemleri, akıllı 1şıklandırma sistemleri, akıllı çöp toplama sistemleri, engellilere yönelik uygulamalar, evde bakım ve uzaktan sağlık uygulamalarının da altyapılarının hazırlanması ve devreye alınması planlamaları ise devam etmektedir (Fortune, 2017). Bir başka akıllı kent projesi de Marmara Denizi ve Karadenizi birleştirecek olan $45 \mathrm{~km}$ uzunluğunda ve $400 \mathrm{~m}$ genişliğinde inşa edilmesi planlanan Kanal İstanbul Projesi'dir (Mangır, 2016:28).

İstanbul Fatih Belediyesi web tabanlı GIS projesi ile dünyada ilk defa kroki bazlı saha çalışmasıyla kat kesitleri ile bağımsız bölümler üç boyutlu sorgulanıp analiz edilebilmekte ve mevcut projelerle karşılaştırılması yapılabilmektedir (Fatih Belediyesi, 2018; Fortune, 2017). Fatih Belediyesi Artırılmış Gerçeklik (augmented reality) uygulamasını da Akıllı Kent projeleri içine almıştır. "FatihAr" uygulaması ile Fatih'te bulunan tarihi, kültürel, kamu alanları ve parsel bilgileri dört farklı dilde sözel, resim, ses ve video olarak görüntülenebilmektedir. Fatih Belediyesi içindeki herhangi bir binanın görüntüsünün fotoğrafı çekilerek ilgili servis merkezine 3G-4G iletişim teknolojisi ile gönderildiğinde, bilgi merkezinden o binaya ilişkin var olan bilgiler kullanıcıya hemen aktarılabilmektedir. Ayrıca ÇEVKO mobil uygulaması ile sahada yapılan yaklaşık 20 farklı temizlik faaliyeti takip ediliyor ve sisteme veriler anlık giriliyor (Fortune, 2017; Uçar vd., 2017:1793).

Ankara genelinde belirli noktalarda trafik yoğunluğu ölçümü yapıldığı ve birkaç noktada akıllı kavşak uygulamaları başlatıldığı görülmektedir. Çöp toplama ile ilgili ilçe belediyelerinin bir kısmında ayrıştırma ve takip sistemleri yer almaktadır. İleri takip yeteneklerine sahip olmasa da Otomatik İtfaiye Komuta Merkezi sistemi kurulmuştur. Ayrıca akıllı kent uygulamaları kapsamında, EGO Genel Müdürlüğü, mobil uygulamalar ile otobüslerin nerede olduğunu, yaklaşık kaç dakika sonra durağa geleceğini, durak ve hat bilgilerini otobüs kullanıcılarına sunmaktadır (Varol, 2017:53-56).

İzmir Büyükşehir Belediyesi, çevreci gemiler, tramvay, metro, banliyö ve elektrikli otobüs filosu projeleriyle karbon salımını azaltmaya çalışırken aynı zamanda tam elektrikli otobüs filosundaki araçlar için gerekli elektriği de ESHOT'un Buca' daki atölye binalarının çatısına kurduğu 10 bin $\mathrm{m}^{2}$ 'lik güneş enerjisi santraliyle karşılamayı planlamıştır (ESHOT’ta “Güneş..., 2018). Ayrıca Ekrem Akurgal Yaşam Parkı'nın elektrik ihtiyacını karşılamak için parkın içindeki spor salonu ve otopark alanlarının çatılarını da enerji tesisine çevirmiştir. Güneş panelleri ile üç ayda 45 bin kilowat saat elektrik enerjisi sağlanarak 19 ton karbondioksit salımının önüne geçilmiştir (Güneş Panelleri.., 2018).

Bursa Büyükşehir Belediyesi kenti akıllı hale getirmek için; Tier 3 sertifikalı veri merkezi, fiber network altyapısı, kişiselleştirilmiş seyahat kart yönetim sistemi, CBS, ilan reklam online denetleme sistemi (IRODES), kameralı araç takip sistemi, zabıta yaka kamera sistemleri, alzheimer ve zihinsel engelli vatandaşların kent yaşamına katılımlarını kolaylaştıracak "Sevgi Çipi" uygulaması (bu sayede hasta yakınları 24 saat hastalarını izleyebilmektedir), evde hasta bakım modülü, müzeler sesli rehber sistemi, lokasyon bazlı SMS bilgilendirme projesi, araç içi internet projesi, mobil platformda hizmet veren üç boyutlu mobil turizm atlası, akıllı yazıcı bask1 kontrol sistemleri, merkezi haberleşme, hafriyat takip sistemi, tıbbi atık toplama sistemi, sinyalize kavşaklar, yeşil dalga sistemi, hizmet binası akıllı aydınlatma sistemi, yangın algılama ve alarm sistemi, dedektörlü kavşaklar, değiştirilebilir mesaj işaretleri (DMI) gibi birçok akıllı uygulama hayata geçirmiştir. Tek yakıtla tüm binanın ısınma ve soğutma ihtiyacının karşılaması projeleri ve akıllı Şehircilik Yol Haritası Standartları Oluşturma Projesi, IoT-asansör takip sistemi, güneş enerjili akıllı bank, uçtan uca akıllı cadde, bulvar projesi, akıllı trafik izleme ve yönetim altyapısı ve merkezi kurulumu, akıllı otoparklar, dijital kütüphane proje çalışmaları da devam etmektedir (Bursa Büyükşehir Belediyesi, 2018). 


\section{SONUÇ}

1980'lerden sonra daha fazla hissedilen kentlerde yaşama arzusu ve özellikle 2000'lerden sonra üretilen teknolojilerin kentlerde sunduğu yeni yaşam biçimleri ve değişen alışkanlıklar kentleşmenin hızını her geçen gün arttırmaktadır. 2025 yılına gelindiğinde dünya nüfusunun yaklaşık \%58'nin kentlerde şehirlerde yaşayacağ 1 , gelişmiş birçok bölgede ve kentte ise bu oranın \%81'i aşacağ tahmin edilmektedir (Amarnath ve diğerleri, 2018). Bu durum vatandaşlara temel kentsel hizmetlerin sürdürülebilir bir şekilde nasıl sunalacağı konusunda yeniden düşünmek zorunda kalan kent planlamacıları, yerel yöneticiler ve kamu yöneticileri için ciddi zorluk analamına gelmektedir. Bu yüzden sınırlı kaynaklarla, giderek artan ve karmaşık hale gelen ihtiyaçları karşılamak için akıllı kent sistemlerinin kurulması adeta bir zorunluluk olarak karşımıza çıkmaktadır.

Günümüz kentleri her türlü dengesizliği içinde barındırmaktadır. Bu nedenle, kentsel mekânlar uygun bir şekilde yönetilemezse, nüfusun büyük bir çoğunluğunun kentlerde yaşadığı dikkate alındığında domino etkisiyle istenmeyen sonuçların ortaya çıkması söz konusu olabilecektir. Nitekim akıllı kent vizyonu yeni bir yapay zekâ, bilgi ve iletişim teknolojileri ile ilişkilendiren fütüristik bir kentin planını ortaya koyarak oluşturulmuştur. Literatürde birçok yazar, akıllı kentin çerçevesini "kentsel zorluklara çözüm” olarak sınırlandırmıştır. Dolayısıyla, iyi bir akıllı kent modelinin yürürlüğe konulabilmesinin yolunun teknolojinin firsatlarından yararlanan iyi bir kent planlamasından geçtiği savunulmuştur. Bu bağlamda bir kentin, akıllı kent olarak değerlendirilebilmesi için; akıllı ekonomi, akıllı yönetişim, akıllı hareketlilik, akıllı çevre, akıllı yaşam, akıllı teknoloji, akıllı altyapı ve en önemlisi tüm bu akıllı çözümleri kabul edip kullanacak akıllı vatandaştan oluşan bir sistemin kurulmas gerekmektedir.

Gelişmişlik düzeyi yüksek, ekonomisi güçlü, sermaye yapısı sağlam ülkelerin akıllı kent pazarında açık ara önde olduğu görülmektedir. Çünkü akıllı kentler çok ciddi bir maliyet ve bilgi ve iletişim teknolojilerinde güçlü bir altyap1 istemektedir. Dünya ölçeğinde yaşanan bu gelişmelerin Türkiye'ye yansımaları değerlendirildiğinde; Türkiye'deki kentlerin bu gelişmelerden etkilendiği ve hemen hemen her kentin çok az da olsa akıllı kent uygulamalarına yer verdiği görülmektedir. Özellikle gelir düzeyi yüksek kentlerin bir adım önde olduğu ve birçok akıllı kent uygulamasının hayata geçirildiği söylenebilir. Bu uygulamaların genellikle akıllı trafik, akıllı park sistemleri, bilgilendirme servisleri, insansız hava araçları ile harita çizimi, engellilere yönelik uygulamalar, kısmen güneş enerjisi panellerinde elektrik üretim olduğu görülmektedir. Bu bağlamda Türkiye'deki akıllı kent uygulamalarının sınırlı olduğu ancak başlanmış olması gelecek adına ümit vadettiği söylenebilir.

Sonuç olarak, insanoğlunun geleceği akıllı kentlerde şekillenecek, yeni nesil kentler daha çok internet üzerinden ve kullanıcı odaklı hizmetlere ağırlık verecektir ve akıllı kentlere en büyük katkıyı bilgi iletişim teknolojileri ile altyapıları sağlayacaktır. Alınacak kararlara tek taraflı değil çok taraflı bir karar mekanizması hâkim olacaktır. Akıllı kentsel çözümlere yatırım yapan ülkelerin/kentlerin gelecekte çok kazançlı çıkacağını, yatırım yapmayan ülkelerle aralarında çok büyük gelişme ve değişme farklılıklarının olacağını tahmin etmek çok da zor değildir. Çünkü akıllı kentler, hem vatandaşlar hem de toplum için ekonomik ve toplumsal değişim ve dönüşümü zorunlu kılmaktadır. Akıllı kentler, daha çok kent ve kentli talepleri için teknolojik ilerleme ve yeniliklerin, vatandaş ve yaşam ekseninde kente nasıl aktarılabileceği hedefli çalışmaları kapsamaktadır. Burada sorunlar daha çok ortaya çıktıktan sonra, eş zamanlı ya da izleri hissedilmeye başladıktan sonra teknoloji destekli çözüm önerisi olarak karşımıza çıkmaktadır. Ancak sorunlar daha ortaya çıkmadan hatta uzak gelecekte olabilecek tüm ihtimalleri hesaplayarak sorunları çok önceden çözümleyen ve çok farklı alternatif yaşamları öngören bilge şehirlere doğru gidildiği/gidileceği düşünülebilir. $\mathrm{Bu}$ bağlamda akıllı kentler bilge kentlere açılan bir ufuk olarak değerlendirilebilir. 


\section{KAYNAKÇA}

ABELLA, Alberto Marta Ortiz-de-Urbina-Criado ve CARMEN, De-Pablos-Heredero (2015), "Information Reuse In Smart Cities' Ecosystems”, El Profesional de la Información, S.6, ss.838-844.

AKDAMAR, Emrah (2017), “Akıllı Kent İdealine Ulaşmada Açık Verinin Rolü”, Sosyal Bilimler Araştırma Dergisi, S.1, ss.45-52.

AKGÜL, Mustafa Kemal (2013), "Kentlerin e-Dönüşümü Akıllı Kentler”, Kalkınmada Anahtar Verimlilik Dergisi, S.291, http://anahtar.sanayi.gov.tr /tr/news/kentlerin-e-donusumu-akillikentler/416 (Erişim Tarihi: 15.12.2017).

AKILLI KENTLER WEB SITESI (2015), “Akill Kentler Nedir", E-Makele, http://www.akillikentler.org/hakkimizda/3/9/-akilli-kentler-nedir.html, (Erişim Tarihi: 19.12.2017).

AKILLI KENTLER WEB SITESI (2016), "Akıllı Kent Yönetim Sistemleri”, E-Makale, http://www.akillikentler.org/yeni-eklenenler/2041/6/akilli-kent-yonetim-sistemleri.html， (Erişim Tarihi: 30.12.2017).

AKILLI KENTLER WEB SITESİ (2016), "Akıllı Kentlerin Temel Taşı", E-Makele, http://www.akillikentler.org/detay/2082/6/ akilli-kentlerin-temel-tasi.html, (Erişim Tarihi: 19.12.2017).

AKILLI KENTLER WEB SİTESİ (2016), "Dijital Ekosistem ve Kentlerin Geleceği”, E-Makale, http://www.akillikentler.org/detay/2084/6/dijital-ekosistem-ve-kentlerin-gelecegi.html, (Erişim Tarihi: 19.12.2017).AKILLI ŞEHİRLER WEB SİTESİ (2017) "Akıllı Şehirler için İnovasyon ve Değişim Rehberi", E-Makale, www.akillisehirler.org/category/makaleler/page/4/, (Erişim Tarihi: 16.12.2017).

AKILLI KENTLER WEB SİTESİ (2016), "Geleceğin Kentlerinde Mobilite", E-Makale, http://www.akillikentler.org/detay/2072/6/gelecegin-kentlerinde-mobilite.html, (Erişim Tarihi: 19.12.2017).

AKILLI KENTLER WEB SITESİ (2016), "Singapur: Aklll Kentlerde Yeni Bir Boyut", E-Makale, http://www.akillikentler.org/detay/2083/6/ singapur-akilli-kentlerde-yeni-bir-boyut.html, (Erişim Tarihi: 20.12.2017).

ALKAN, Tunay (2015), “Akıllı Kentler ya da 21. Yüzyıl Şehirleri”, Bilişim Dergisi, S.182, ss.70-77.

AMARNATH, Archana, SINGH, Sarwant ve PARRISH, Karen, “Analyst Briefing: Global Smart City Market A $\$ 1.5$ Trillion Market Opportunity by 2020", E-Article, http://www.frost.com/prod/servlet/analystbriefing-detail.pag? mode $=$ open $\&$ sid= $=280678953$, (Erişim Tarihi: 07.01.2018).

ASÜD (2016), “Akıllı Şehir Nedir? Türkiye'de Akıllı Şehir Uygulamaları", E-Haber, https://www.asuder.org.tr /akilli-sehir-nedir-turkiyede-akilli-sehir-uygulamalari/, (Erişim Tarihi: 28.12.2017).

BATTY, Michael (2013), "Big Data, Smart Cities And City Planning”, Dialogues in Human Geography, S.3, ss.274-279.

BENNETT, Dag, YABAR, Diana Perez-Bustamante ve MEDRANO, Maria-Luisa (1996), "Challenges For Smart Cities In The UK", Methods, S.100, ss.1-7.

BİÇAKCI, Harun (2014), "Yeni Kent Tasarımı ve Akıllı Kentler: Karşılaştırmalı Bir Analiz ve Samsun İçin Model Önerisi”, Yüksek Lisans Tezi, Ondokuzmayıs Üniversitesi Sosyal Bilimler Enstitüsü, Samsun.

BİLİCI, Zekeriya ve BABAHANOĞLU, Veysel (2018), "Akıllı Kent Uygulamaları ve Konya Örneği”, Akademik Yaklaşımlar Dergisi, S.9(2), ss.124-139.

BULUT, Canan (2018), "Bulut Bilişim (Cloud Computing) Nedir?", E-Makale, https://www.endustri40.com/bulut-bilisim-cloud-computing-nedir/, (Erişim Tarihi : 19.03.2019).

BURSA BÜYÜKŞEHIR BELEDIYYSİ (?Tarihsiz), “Akıllı Belediyecilik ve Akllı Şehircilik Uygulamaları”, ESunum, https://www.bursa.bel.tr/dosyalar/birimek/akilli-belediyecilik-ve-akilli-sehircilikuygulamalari.diger.79hP5VaEDB..pdf, (Erişim Tarihi: 07.01.2018).

CHOURABI, Hafedh, NAM, Taewoo, WALKER, Shawn, GIL-GARCIA, J. Ramon, MELLOULI, Sehl, NAHON, Karine, A. PARDO, Theresa ve SCHOLL, Hans Jochen (2012), “Understanding Smart Cities: 
An Integrative Framework", Proceedings of the Annual 45. Hawaii International Conference on System Sciences, ss.2289-2297.

CITIES IN MOTION (2018), "IESE Cities in Motion Index 2018", E-Article, https://blog.iese.edu/citieschallenges-and-management/2018/05/23/iese-cities-in-motion-index-2018/, (Erişim Tarihi :19.03.2019).

ÇELIKYYAY, Hicran Hamza (2008), “Teknoloji Girdabindan Akıllı Şehre Dönüşüm : İstanbul Örneği”, II. Türkiye Lisanüstü Çalışmaları Kongresi - Bildiriler Kitabı V, ss.1315-1328.

ÇERÇİ, İ. Nejat (2015), “Akıllı kentler, Bir Ihtiyaç ve Geleceğe Dönük Bir Yaşam Modelidir”, Bilişim Dergisi, S.172, ss.196-201.

DELOITTE (2016), “Akıllı Şehir Yol Haritası”, E-Makale, https://www.sehirsizin.com/Documents/ DeloitteVodafone-Akilli-Sehir-Yol-Haritasi.pdf, (Erişim Tarihi: 05.12.2017).

ELVAN, Lütfi (2017), “Akıllı Şehirler: Lüks Değil İhtiyaç”, İTü Vakfı Dergisi, S.77, ss.6-9.

FATİH BELEDIYESİ (?Tarihsiz), "Coğrafi Bilgi Sistemi", E-Sistem, https://gis.fatih.bel.tr/webgis/default.aspx, (Erişim Tarihi: 05.01.2018).

FORTUNE (2017), "Yol Açın! Akıllı Şehirler Geliyor", E-Haber, http://www.fortuneturkey.com/yol-acin-akillisehirler-geliyor-45878, (Erişim Tarihi: 28.12.2017).

GIFFINGER, Rudolf (2007), “Smart Cities Ranking Of European Medium-Sized Cities", Vienna University of Technology Research Report, October, ss.13-18.

GIFFINGER, Rudolf ve GUDRUN, Haindlmaier (2010), "Smart Cities Ranking: An Effective Instrument For The Positioning Of The Cities?", ACE: Architecture, City and Environment, S.12, ss.7-26.

GLASMEIER, Amy ve CHRISTOPHERSON, Susan (2015), "Thinking About Smart Cities", Cambridge Journal of Regions, Economy and Society, S.1, ss.3-12.

GOODSPEED, Robert (2015), "Smart Cities: Moving Beyond Urban Cybernetics To Tackle Wicked Problems", Cambridge Journal of Regions, Economy and Society, S.1, ss.79-92.

GÜL, Ayça ve ATAK ÇOBANOĞLU, Şermin (2017), “Avrupa'da Akıllı Kent Uygulamalarının Değerlendirilmesi ve Çanakkale'nin Akıllı Kente Dönüşümünün Analizi”, SDÜ İktisadi ve İdari Bilimler Fakültesi Dergisi, Kayfor15 Özel Sayısı, ss.1543-1565.

GÜLSEÇEN, Sevinç, ÖZDEMIR, Şebnem, ÇELIK, Serra, UĞRAŞ, Tuba ve ÖZCAN, Mustafa (2013), “Dijital Dünyadan Yansımalar Bilgide ve Vatandaşlıkta Değişim", XVIII. Türkiye'de İnternet Konferansı Bildiri Kitapçığı, İstanbul Üniversitesi Yayını, ss.223-227.

GÜRSOY, Oğuzhan (2019), "Akıllı Kent Yaklaşımı ve Türkiye'deki Büyükşehirler İçin Uygulama İmkanları", Yüksek Lisans Tezi, Hacettepe Üniversitesi Sosyal Bilimler Enstitüsü, Ankara.

HARRISON, Colin ve DONNELLY, Ian Abbott (2011), "A Theory of Smart Cities", Proceedings of the 55th Annual Meeting of the ISSS - 2011, Hull, UK, ss.1-15.

HARRISON, Colin, ECKMAN, Barbara, HAMILTON, Rick, HARTSWICK, Perry, KALAGNANAM, Jayant, PARASZCZAK, Jurij ve WILLIAMS, Peter (2010), "Foundations For Smarter Cities", IBM Journal of Research and Development, S.4, ss.1-16.

HERZBERG, Caspar (2017), Akıllı Şehirler Dijital Ülkeler (Çev. Nadir Özata), İnfoloji-Optimist Yayın Dağıtım, İstanbul.

HOLLANDS, Robert G. (2008), Will The Real Smart City Please Stand Up? Intelligent, Progressive or Entrepreneurial?, Routledge, New York (USA).

İSBAK (?Tarihsiz), "Akıllı Şehrin Mimarı: ISBAK”, E-Makale, http://isbak.istanbul/akilli-sehirler-3/, (ErişimTarihi: 28/12/2017).

İSTANBUL BÜYÜKŞEHIR BELEDIYE BAŞKANLIĞI (2017), “iBBB Türkiye'nin İlk Uluslararası Standartta Veri Merkezini Kurdu”, E-Haber, https://www.ibb.istanbul/News/Detail/34231, (Erişim Tarihi: 30.12.2017). 
ÖRSELLİ, Erhan ve AKBAY, Can - Teknoloji ve Kent Yaşamında Dönüşüm: Akıllı Kentler

İZMIR BÜYÜKŞEHIR BELEDIYE BAŞKANLIĞI (2017), “ESHOT’ta “Güneş Enerjisi Devrimi”, E-Haber, https://www.izmir.bel.tr/tr/Haberler/eshotta-gunes-enerjisi-devrimi/23491/156, (Erişim Tarihi: 02.01.2018).

İZMIR BÜYÜKŞEHIR BELEDIYE BAŞKANLIĞI (2017), “Güneş Panelleri Çoğalıyor, İzmir Kazanıyor”, EHaber, https://www.izmir.bel.tr/HaberDetay/31061/tr, (Erişim Tarihi: 02.01.2018).

KAMP, Jesper (2015), “Ekoyapı”, Ekolojik Yapı ve Yerleşimler Dergisi, S.24, ss.136-139.

KES ERKUL, Aysu (2017), "Akıllı Kentler Bilgi Notu”, E-Makale, http://kaytek-tr.org/Akent.doc, (Erişim Tarihi: 06.12.2017).

KOMNINOS, Nicos (2008), Intelligent Cities and Globalisation of Innovation Networks, Routledge, New York (USA).

KOMNINOS, Nicos (2015), The Age Of Intelligent Cities, Routledge, New York (USA).

KÖKCIYAN, Nadin ve YOLUM, Pınar (2017), “Akıllı Sehirler için Mahremiyet Yönetimi”, 2017 25th Signal Processing and Communications Applications Conference (SIU), Antalya, ss.1-4.

LEE, Jung Hoon, HANCOCK, Marguerite Gong ve HU, Mei Chih (2014), "Towards An Effective Framework For Building Smart Cities: Lessons From Seoul And San Francisco", Technological Forecasting and Social Change, ss.80-99.

MANGIR, Fatih (2016), "Smart City: Strategies For Local Governments: The Case Of Konya In Turkey", Selçuk Üniversitesi Sosyal Bilimler Meslek Yüksekokulu Dergisi, 41.Yıl Özel Sayısı, ss.17-36.

MCKINSEY COMPANY (2013), "Bilgi Toplumu Stratejisinin Yenilenmesi Projesi", Bilgi ve İletişim Teknolojileri Destekli Yenilikçi Çözümler Ekseni Mevcut Durum Raporu, T. C. Kalkınma Bakanlığı Bilgi Toplumu Dairesi Yayını, Ankara.

NTBOX Magazin (2017), “Akullı Şehirler: Dijital Dünya", E-Makale, http://www.ntboxmag.com/2017/10/25/akilli-sehirler-dijital-dunya/, (Erişim Tarihi: 20/12/2017).

OJO, Adegboyega, DZHUSUPOVA, Zamira ve CURRY, Edward (2016), "Exploring the Nature of the Smart Cities Research Landscape", Smarter as the New Urban Agenda: Public Administration and Information Technology (Ed. J. Gil-Garcia, T. Pardo, T. Nam), Springer International Publishing, Switzerland, ss.23-47.

ÖRSELLİ, Erhan, BİLİCİ, Zekeriya ve BABAHANOĞLU, Veysel (2018). “Akıllı Vatandaş, Akıllı Kentler ve Türkiye”, ICPESS 2018 Proceedings Vol. 1: Political Studies, ss.1-14.

ÖZHASEKİ, Mehmet (2017), "Akıllı Kentler Stratejisi Eylem Planı Hazırlaniyor", E-Haber, https://haber.tobb.org.tr/ekonomikforum/2017/278/018-031.pdf, (Erişim Tarihi: 01/01/2018).

RABARI, Chirag ve STORPER, Michael (2015), "The Digital Skin Of Cities: Urban Theory And Research In The Age Of The Sensored And Metered City, Ubiquitous Computing And Big Data", Cambridge Journal of Regions, Economy and Society, S.1, ss.27-42.

SCHAFFERS, Hans, KOMNINOS, Nicos, PALLOT, Marc, TROUSSE, Brigitte, NILSSON, Michael ve OLIVEIRA, Alvaro (2011), "Smart Cities And The Future Internet: Towards Cooperation Frameworks For Open Innovation", Future Internet Assembly (Ed. J. Domingue), Springer, New York (USA), ss. 431-446.

SHAPIRO, Jesse M. (2006), "Smart Cities: Quality Of Life, Productivity, And The Growth Effects Of Human Capital", The Review of Economics And Statistics, S.2, ss.324-335.

ŞAHIN, Ali (2016), Türk Kamu Yönetiminde Yapısal Dönüşüm ve E-Devlet, Atlas Akademi Yayını, Konya, 3. Bask1.

ŞAHIN, Ali ve ÖRSELLİ, Erhan (2003), “E-Devlet Anlaylşı Sürecinde Türkiye”, Selçuk Üniversitesi Sosyal Bilimler Enstitüsü Dergisi, S.9, ss.343-356.

ŞENOL, Selma (2017), “Türkiye'de 26 Akıllı Kent Oluşacak”, Emlak Konut Dergisi, S.Haziran, ss.50-52.

TAWNSEND, Anthony M. (2013), Smart Cities, W.W. Norton \& Company Inc., New York (USA). 
TÜRK TELEKOM (?Tarihsiz), “Akıllı Şehirler”, E-Haber, http://www.sehirlerakillaniyor.com/, (Erişim Tarihi: 14.01.2018).

UÇAR, Ahmet, ŞEMŞIT, Sühal ve NEGIZ, Nilüfer (2017), “Avrupa Birliği Akıllı Kent Uygulamaları ve Türkiye'deki Yansımaları”, SDÜ İktisadi ve İdari Bilimler Fakültesi Dergisi, Kayfor15 Özel Sayıs1, ss.1785-1798.

VANOLO, Alberto (2014), "Smartmentality: The Smart City as Disciplinary Strategy", Urban Studies, S.5, ss.883-898.

VAROL, Çiğdem (2017), "Sürdürülebilir Gelişme de Akıllı Kent Yaklaşımı: Ankara'daki Belediyelerin Uygulamaları", Çağdaş Yerel Yönetimler, S.1, ss.43-58.

VELİBEYOĞLU, Koray (2019), “Akıllı Kentler: Vaatler ve Ötesi”, Yenilikçi Sürdürülebilir Gelişme Stratejileri Bağlamında Türkiye Ekonomisinin Geleceğine Yönelik Çözüm Arayışları (Ed. S. Şanlısoy), İlkim Ofset, İzmir, https://www.researchgate.net/publication/326679527_AKILLI_KENTLER_VAATLER_VE_OTESI, (Erişim Tarihi: 18.03.2019).

XSIGHTS (2016), "Akıllı Kentler Masabaşı Araştırması-Kamu Teknoloji Platformu", E-Haber, https://www.xsights.co.uk/tr/xsights-akilli-sehir-cozumleri-5668/ (Erişim Tarihi: 03.01.2018). 